\title{
Morphological Characteristics and Body Composition of Elite Soccer Players in Montenegro
}

\author{
Características Morfológicas y Composición Corporal de Futbolistas de Élite en Montenegro
}

\author{
Jovan Gardasevic $^{1}$; Dusko Bjelica ${ }^{1}$ \& Ivan Vasiljevic ${ }^{1}$
}

\begin{abstract}
GARDASEVIC, J.; BJELICA, D. \& VASILJEVIC, I. Morphological characteristics and body composition of elite soccer players in Montenegro. Int. J. Morphol., 37(1):284-288, 2019.

SUMMARY: The aim of this research was to determine the differences among the soccer players of three the most successful clubs in Montenegro, FC Buducnost, FC Mladost and FC Sutjeska in a terms of morphological characteristics and body composition. A sample of 70 subjects was divided into three sub-samples. The first sub-sample of the subjects consisted of 30 players of FC Buducnost of the average age 22.73 \pm 4.33 , the champions of Montenegro in the season 2016/17, the other sub-sample consisted of 17 players of FC Mladost of the average age of 24.59 \pm 4.66 , the vice champions of the Montenegrin Championship in the season 2016/17, and the last subsample of the examinees consisted of 23 players of FC Sutjeska of the average age 21.69 \pm 4.30 , the champions of the Cup of Montenegro in the season 2016/17. Soccer players were tested immediately after the end of the competition season 2016/17. Morphological characteristics in the body composition were evaluated by a battery of 11 variables: body height, body weight, body mass index, fat percentage, muscle mass, bone mass, waist circumference, triceps skinfold, biceps skinfold, skinfold of the back and abdominal skinfold. Data were analyzed using SPSS and the descriptive statistics were expressed as a mean (SD) for each variable. The significance of the differences between the players of the three the most successful soccer clubs in the morphological characteristics and variables for assessing body composition were determined by ANOVA and LSD Post Hoc test. ANOVA test found that the soccer players of the three mentioned clubs have statistically significant differences by the two variables that estimate the fat percentage and skinfold of the back. LSD Post Hoc test found that the soccer players of FC Sutjeska are significantly better in these variables than other players.
\end{abstract}

KEY WORDS: Morphological Characteristics; Body composition; Soccer; Montenegro.

\section{INTRODUCTION}

A soccer game is said to be the most important secondary event in the world, it gathers huge masses at stadiums and in front of TVs (Gardasevic et al., 2017). It is a highly dynamic and fast team game which, with its richness of movement, falls under the category of polystructural sports games. Soccer is a sport that is characterized by numerous and various complex and dynamic kinesiological activities which are then characterized by either cyclical or acyclical movement (Sermaxhaj et al., 2017). In soccer, top score can be achieved only under conditions of well-programmed training process. High quality management of the training process depends on the knowing of the structure of certain anthropological capabilities and player's characteristics, as well as their development. Various researches are to be done in order to establish certain principles and norms for the transformational processes of the anthropological characteristics important for soccer. However, in many places much more time is spent on increasing the physical fitness of athletes without taking into consideration the assessment of their body composition and their nutritional status (Triki et al., 2012). Findings regarding morphological characteristics and body composition are of crucial importance for complex sports games such as soccer. The morphological space is defined by the longitudinal dimension of the skeleton, the transversal dimensionality of the skeleton and the mass and volume of the body. The purpose of knowing morphological characteristics is to improve skills in many sports (Carter \& Heath, 1990). The morphological status of top level athletes is relatively homogeneous, depending on the sport, and it can be defined as a model of athletic achievement (Misigoj-Durakovic et al., 1995). Research on morphological characteristics and body composition among athletes of different sports indicates that athletes of different sports have their own specific characteristics, mostly due to the reason that absolute size contributes a significant percentage of total variance 
associated with athletic success (Carvajal et al., 2012). Muscle mass improves performance in activities that require muscular strength and endurance, but also in those that require enviable aerobic ability (Ramadan \& Byrd, 1987; Green, 1992; Rico-Sanz, 1998). The athlete's belonging to a sports branch gives to an athlete certain morphological characteristics and body compositions. It gives him the advantage of dealing with this sport in relation to others.

Today, soccer is certainly the number one sport in the world for its rating and popularity, and the same applies to Montenegro. The First League of Montenegro is the top soccer league in Montenegro. It is headed by the Soccer Association of Montenegro. Ten teams participate in this league. The winner of the Montenegrin First League starts the qualifications for the UEFA Champions League from the second round. The second placed team and the National Cup winner play in the qualifying rounds of the UEFA Europa League. The three clubs that are at the top of the First League of Montenegro and are competing for trophies almost every year are Socer Club Buducnost (hereinafter FC Buducnost), Socer Club Mladost (hereinafter FC Mladost) and Socer Club Sutjeska (hereinafter FC Sutjeska). In the 2016/17 competitive season, all of the three clubs have achieved a staggering success, FC Buducnost was the champion of Montenegro, FC Mladost was the vice champion of Montenegro and FC Sutjeska won the Cup of Montenegro. Based on results at the end of the competition season, these three clubs have acquired the right to play on the international soccer scene within the framework of UEFA's competitions. It became as interesting for researchers to determine the models of anthropometric characteristics and body composition of the players who play for these clubs as to determine the differences among them.

The aim of this research was to analyze the differences in some morphological characteristics and body composition among top soccer players, players of FC Buducnost, FC Mladost and FC Sutjeska, who compete in the First League of Montenegro.

\section{MATERIAL AND METHOD}

The data obtained in the study of morphological characteristics and body composition are checked and prepared for processing according to the set goal. Data bases are arranged according to the features and prepared for planned statistical processing. The results obtained by statistical analysis are presented in the tables and analyzed by the corresponding logical units. In general, the results of the research, through gradual explanation of individual relationships, allow us to determine differences in the observed morphological measures and body composition in accordance with the aim of the research. That is, they contribute to a clearer application of the obtained results in practice. In terms of time constraint, the research is transversal, and it consists of one-off measurement of the corresponding morphological characteristics and body composition of top-level senior players.

Sample of subjects. A sample of the subjects consisted of a total of 70 top-level senior players who performed in the First League of Montenegro, divided into three sub-samples. The first sub-sample of the subjects consisted of 30 players of FC Buducnost of the average age $22.73 \pm 4.33$, the champions of Montenegro in the season 2016/17, the other sub-sample consisted of 17 players of FC Mladost of the average age of $24.59 \pm 4.66$, the vice champions of the Montenegrin Championship in the season 2016/17, and the last sub-sample of the examinees consisted of 23 players of FC Sutjeska of the average age 21.69 \pm 4.30 , the champions of the Cup of Montenegro in the season 2016/17. The soccer players were tested immediately after the season 2016/17 ended.

Sample of measures. Anthropometric research was carried out with respect to the basic rules and principles related to the selection of measuring instruments and measurement techniques standardized in accordance with the International Biological Program guidelines. For the purpose of this study, 7 morphological measures have been taken: body height, body weight, waist circumference, triceps skinfold, biceps skinfold, skinfold of the back, abdominal skinfold, and 4 body composition assessment variables: body mass index, fat percentage, muscle mass and bone mass. Anthropometer, caliper, and measuring tape were used for morphological measurements. To evaluate the body composition, Tanita body fat scale - model BC-418MA, was used. The principle of this scale is based on indirect measurement of the body composition; a safe electrical signal is transmitted through the body via electrodes located in the standalone unit. The Tanita Scale, thanks to its athletics mode, enables athletes to closely monitor their body weight, health condition and form with all relevant parameters.

Method of data processing. The data obtained through the research were processed by descriptive and comparative statistical procedures. For each variable, central and dispersion parameters have been processed. The significance of the differences between the players of the three the most successful soccer clubs in the morphological characteristics and variables for assessing body composition was determined by ANOVA and LSD Post Hoc tests, with statistical significance of $\mathrm{p}<0.05$. 
RESULTS

The variables for assessing morphological characteristics and body composition of subjects are shown in Table I.

There were significant differences in two variables among the soccer players of the three clubs. A significant difference was found for skinfold of the back $(\mathrm{F}=3.62)$ and fat percentage $(\mathrm{F}=6.80)$.

The significant differences of skinfold of the back and fat percentage among the soccer players of these three clubs are shown in Figures 1 and 2.

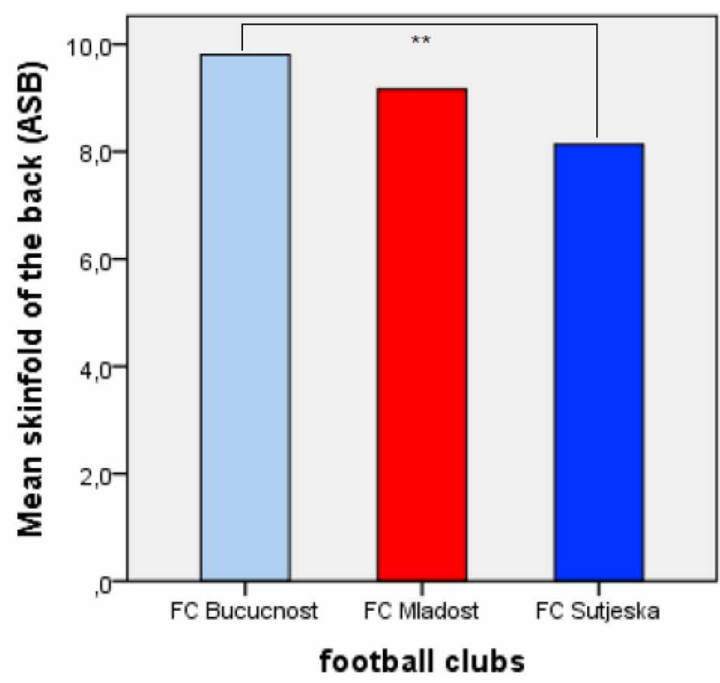

Fig. 1. LSD Post Hoc test for the skinfold of the back **= significance $\leq 0.01$
The LSD Post Hoc test showed that soccer players of FC Buducnost had significantly higher values of skinfold of the back compared to the soccer players of FC Sutjeska.

The LSD Post Hoc test showed that fat content in the body of soccer players of the three clubs from this study was significantly different where soccer players of FC Sutjeska had the lowest fat percentage, while the soccer players of FC Mladost had the highest fat percentage and they are statistically significantly differed from the soccer players of FC Sutjeska $(\mathrm{p}<0.01)$ and from the soccer players of FC Buducnost $(\mathrm{p}<0.05)$.

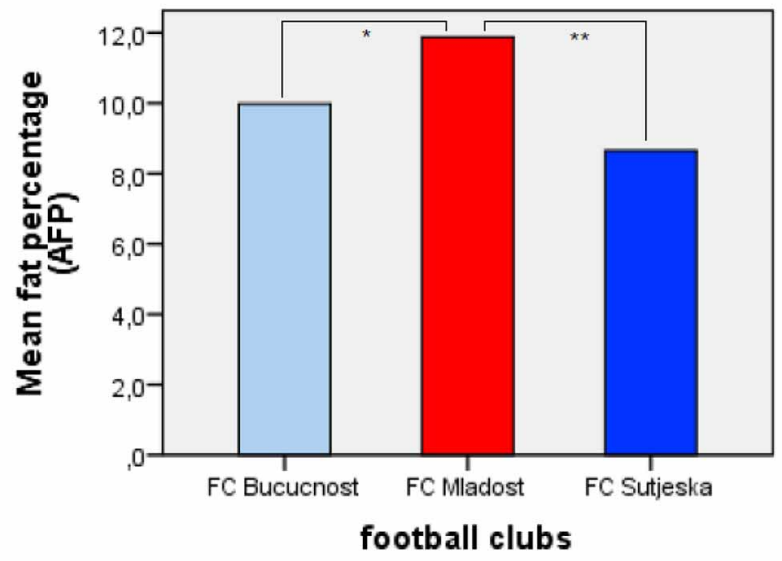

Fig. 2. LSD Post Hoc test for the fat percentage $* *=$ significance $\leq 0.01 ; *$ significance $\leq 0.05$

Table I. Descriptive data and ANOVA of 70 soccer players, members of the three clubs

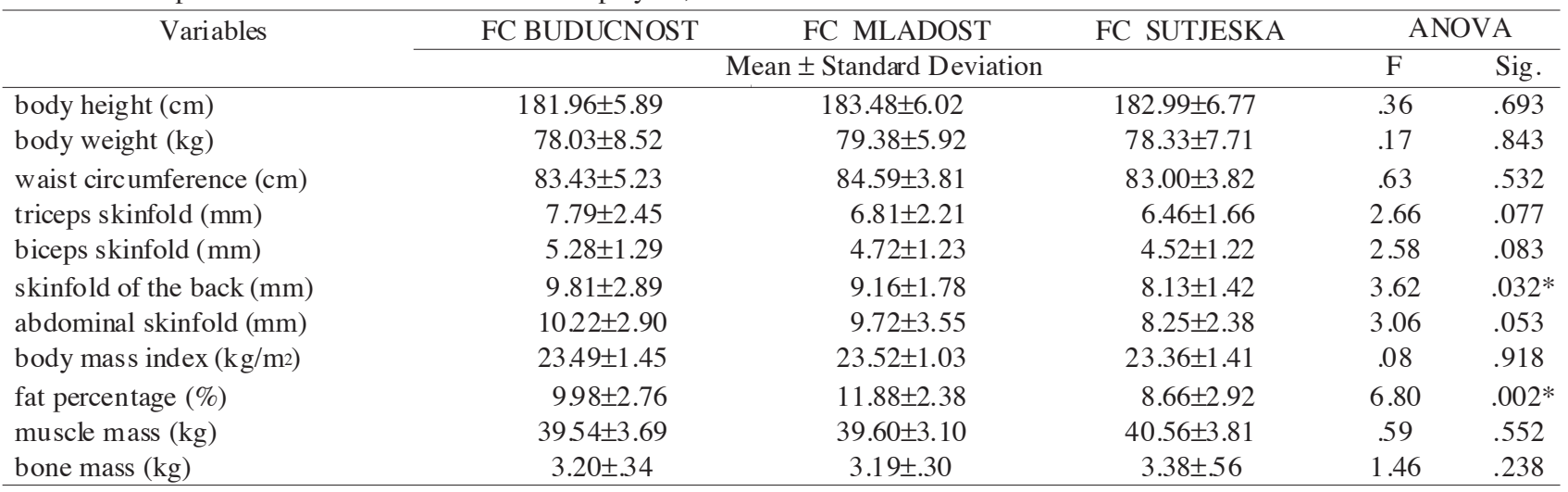




\section{DISCUSSION}

By looking into the basic descriptive statistical parameters, it can be concluded that we have examined professional sportsmen. It can be noticed that the soccer players of these three clubs are of the approximately similar mean values of the variables analyzed, which is not surprising because these are the top three clubs in Montenegro, a state where there is also a concentration of the best players. The ANOVA showed a statistically significant difference only in two variables. The first is skinfold of the back and the second is fat percentage. The LSD Post Hoc test showed that the players of FC Buducnost have significantly higher values of skinfold of the back than the players of FC Sutjeska. Soccer players of FC Sutjeska have shown statistically better values because a smaller number means a better result when the disrupting factor of subcutaneous fat on playing soccer is taken into account. The second variable in which a statistically significant difference has been found is a variable that estimates body composition, fat percentage. The LSD Post Hoc test shows that the soccer players of FC Sutjeska had the significantly lowest fat percentage compared to the soccer players of FC Mladost $(\mathrm{p}<0.01)$ and soccer players of FC Buducnost $(p<0.05)$. Also, the soccer players of FC Buducnost had the significantly lower fat percentage compared to the soccer players of FC Mladost $(\mathrm{p}<0.05)$. Moreover, it is wellknown that low fat percentage is desirable for high physical performance in all sports. Although, not every body composition characteristic is expected to play a role in optimal performance in professional soccer, lower levels of body fat (that are specific to each player) are desirable for optimal performance as body mass must be moved against gravity (Rienzi et al., 2000; Gil et al., 2005). In other words, by achieving optimal levels of body fat and fat-free mass, the player can minimize the negative effects of excess body fat without sacrificing skill.

Table II. Descriptive data of all 70 soccer players

\begin{tabular}{lccc}
\hline \multicolumn{1}{c}{ Variables } & Min & Max & Mean \pm Std. Dev. \\
\hline age & 17 & 35 & $22.84 \pm 4.47$ \\
body height $(\mathrm{cm})$ & 166 & 196 & $182.67 \pm 6.16$ \\
body weight $(\mathrm{kg})$ & 64.7 & 96.9 & $78.45 \pm 7.60$ \\
waist circumference $(\mathrm{cm})$ & 74 & 95 & $83.57 \pm 4.46$ \\
triceps skinfold $(\mathrm{mm})$ & 3 & 14 & $7.11 \pm 2.21$ \\
biceps skinfold $(\mathrm{mm})$ & 3.1 & 8.2 & $4.89 \pm 1.28$ \\
skinfold of the back $(\mathrm{mm})$ & 3.6 & 18.6 & $9.09 \pm 2.33$ \\
abdominal skinfold $(\mathrm{mm})$ & 5.4 & 18.2 & $9.45 \pm 3.00$ \\
body mass index $\left(\mathrm{kg} / \mathrm{m}^{2}\right)$ & 21.1 & 27.1 & $23.45 \pm 1.33$ \\
fat percentage $(\%)$ & 2.6 & 16.1 & $10.00 \pm 2.95$ \\
muscle mass $(\mathrm{kg})$ & 34.1 & 46.9 & $39.89 \pm 3.57$ \\
bone mass $(\mathrm{kg})$ & 2.7 & 5.0 & $3.26 \pm 0.42$
\end{tabular}

However, despite the significant differences all the soccer players had a lower percentage of fat and these results were expected, because many of the previous research recognized soccer as a predominantly aerobic sport (Kemi et al., 2003; Stølen et al., 2005). Furthermore, it is very important to soccer players to have a determined body fat percentage in order to perform well enough and achieve their full playing potential. The fat percentage soccer players of English Premier League vary from 9.9 percent to 12.9 percent, depending on the position (Sutton et al., 2009), in Japan 8.5-13.7\% depending on the position (Tahara et al., 2006), in Zimbabwe 9.2-11.2\% depending on the position (Masocha \& Katanha, 2014). However, these are just guidelines and the players would work together with their coaches to determine the individual body fat percentage to enhance their physical abilities and their health. The importance of body composition in sport performance is a primary concern in creating athletes profiles as well as conditioning programs throughout a season at all levels of competition (Silvestre et al., 2006), in that describing anthropometric characteristics and body compositions of athletes and detecting possible differences in relation to competition levels may give coaches a better working knowledge of the studied groups of athletes.

For other variables, some values are better for players of FC Buducnost, some for players of FC Mladost and some for players of FC Sutjeska, although, insignificantly for statistics, which indicates that these players have very similar anthropometric parameters and body composition, which is again, not surprising, considering that these two clubs FC Buducnost and FC Sutjeska shared the two trophies in the 2016/17 competitive season in Montenegro, while FC Mladost was a vice champion. Given that the concentration of the best soccer players in Montenegro is in these 3 clubs, the assumption is that the mean values of the analyzed variables in all of them should be the model values for the soccer players of other clubs (Table II).

The results obtained in this research can serve as model parameters for the estimated variables for players of all other soccer clubs in Montenegro, because the players that have been analyzed here were among the best and the most successful soccer players in Montenegro at the end of the competitive season of the First League of Montenegro 2016/17. Similar results with elite soccer players received Corluka et al. (2018) in Bosnia and Herzegovina, Popovic et al. $(2013,2014)$ in Serbia, because the quality of soccer in this region of ex Yugoslavia is very similar. 
As for average height of socker players in Montenegro, comparing to all the participants in the 2018 World Soccer Championship in Russia which was 181.70 centimeters, while the average height of all players from Croatia league was $(183.60 \mathrm{~cm})$, Germany $(183.5 \mathrm{~cm})$, Denmark $(183.5 \mathrm{~cm})$, Poland $(183 \mathrm{~cm})$, showed by an official statistical data proved, that soccer players in Montenegro are tall enough and very similar to the average players in the listed European leagues. The tendency to recruit taller soccer players is not unsworn in the scientific literature yet (Popovic et al., 2012).

The values obtained in this research can be useful for coaches of other clubs for making a comparison of their soccer players with the best soccer players in Montenegro and formulate their training in a way that enables reduction of those parameters that are not good, and raise those that are good to a higher level. That will surely make their soccer players even better and more successful. Also, socker clubs in Montenegro should turn to other research and check the functional-motor status, psychological preparation as well as tactical training of their players and analyze whether there is a room for improvement.

GARDASEVIC, J.; BJELICA, D. \&VASILJEVIC, I. Características morfológicas y composición corporal de futbolistas de élite en montenegro. Int. J. Morphol., 37(1):284-288, 2019.

RESUMEN: El objetivo de esta investigación fue determinar las diferencias entre los futbolistas de los tres clubes más exitosos de Montenegro, FC Buducnost, FC Mladost y FC Sutjeska en términos de sus características morfológicas y de su composición corporal. Una muestra de 70 sujetos fue dividida en tres submuestras. La primera sub-muestra consistió en 30 jugadores del FC Buducnost con edades promedio de 22,73 $\pm 4,33$ años, campeones de Montenegro en la temporada 2016/17. La otra sub-muestra consistió en 17 jugadores del FC Mladost con edad promedio de 24,59 \pm 4,66 años, vice campeones del Campeonato de Montenegro en la temporada 2016/17. La última sub-muestra consistió en 23 jugadores del FC Sutjeska con edad promedio 21,69 \pm 4,30 años, campeones de la Copa de Montenegro. Los jugadores de fútbol se pusieron a prueba inmediatamente después de la final de temporada de competición 2016/17. Las características morfológicas en la composición corporal se evaluaron mediante una batería de 11 variables: altura corporal, peso corporal, índice de masa corporal, porcentaje de grasa, masa muscular, masa ósea, circunferencia de la cintura, pliegue cutáneo tríceps, pliegue cutáneo bíceps, pliegue cutáneo de la espalda y pliegue cutáneo abdominal . Los datos se analizaron mediante SPSS y las estadísticas descriptivas se expresaron como una media (DE) para cada variable. La importancia de las diferencias entre los jugadores de los tres clubes de fútbol más exitosos en cuanto a las características morfológicas y las variables para evaluar la composición corporal se determinó mediante la prueba ANOVA y LSD Post Hoc. La prueba ANOVA encontró que los jugadores de fútbol de los tres clubes mencionados tienen diferencias estadísticamente significativas para las dos variables que estiman el porcentaje de grasa y el pliegue cutáneo de la espalda. La prueba LSD Post Hoc encontró que los jugadores de fútbol del FC Sutjeska son significativamente mejores en estas variables que otros jugadores.

PALABRAS CLAVE: Características morfológicas; Composición corporal; Futbol; Montenegro.

\section{REFERENCES}

Carter, J. E. L. \& Heath, B. H. Somatotyping-Development and Application. Cambridge, Cambridge University Press, 1990.

Carvajal, W.; Betancourt, H.; León, S.; Deturnel, Y.; Martínez, M.; Echevarría, I.; Castillo, M. E. \& Serviat, N. Kinanthropometric profile of Cuban women Olympic volleyball champions. MEDICC Rev., 14(2):16-22, 2012.

Corluka, M.; Bjelica, D.; Vasiljevic, I.; Bubanja, M.; Georgiev, G. \& Zeljko, I. Differences in the morphological characteristics and body composition of football players of HSC Zrinjski Mostar and FC Siroki Brijeg in Bosnia and Herzegovina. Sport Mont, 16(2):77-81, 2018

Gardasevic, J.; Bjelica, D. \& Vasiljevic, I. The strength of kicking the ball after preparation period with U15 football players. Sport Mont, 15(2):39-42, 2017.

Green, S. Anthropometric and physiological characteristics of SouthAustralian soccer players. Aust. J. Sci. Med. Sport, 24(1):3-7, 1992.

Kemi, O. J.; Hoff, J.; Engen, L. C.; Helgerud, J. \& Wisløff, U. Soccer specific testing of maximal oxygen uptake. J. Sports Med. Phys. Fitness, 43(2):139-44, 2003.

Masocha, V. \& Katanha, A. Anthropometry and somatotype characteristics of male provincial youth league soccer players in Zimbabwe according to playing positions. Int. J. Sci. Res., 3(3):554-7, 2014.

Misigoj-Durakovic, M.; Matkovic, B. \& Medved, R. Morphological anthropometry in sports. Zagreb, Fakultet za Fizicku Kulturu, 1995.

Popovic, S.; Akpinar, S.; Jaksic, D.; Matic, R. \& Bjelica, D. Comparative study of anthropometric measurement and body composition between elite soccer and basketball players. Int. J. Morphol., 31(2):461-7, 2013.

Popovic, S.; Bjelica, D.; Jaksic, D. \& Hadzic, R. Comparative study of anthropometric measurement and body composition between elite soccer and volleyball players. Int. J. Morphol., 32(1):267-74, 2014.

Popovic, S.; Bjelica, D.; Petkovic, J. \& Muratovic, A. Comparative Study of Anthropometric Measurement and Body Composition between Elite Soccer and Handball Players. Split, 4th International Scientific Conference "Contemporary Kinesiology". Faculty of Kinesiology, University of Split, 2012.

Ramadan, J. \& Byrd, R. Physical characteristics of elite soccer players. J. Sports Med. Phys. Fitness, 27(4):424-8, 1987.

Rico-Sanz, J. Body composition and nutritional assessments in soccer. Int. J. Sport Nutr., 8(2):113-23, 1998

Rienzi, E.; Drust, B.; Reilly, T.; Carter, J. E. \& Martin, A. Investigation of anthropometric and work-rate profiles of elite South American international soccer players. J. Sports Med. Phys. Fitness, 40(2):162-9, 2000.

Sermaxhaj, S.; Popovic, S.; Bjelica, D.; Gardasevic, J. \&Arifi, F. Effect of recuperation with static stretching in isokinetic force of young football players. J. Phys. Educ. Sport, 17(3):1948-53, 2017.

Silvestre, R.; West, C.; Maresh, C. M. \& Kraemer, W. J. Body composition and physical performance in men's soccer: a study of a National Collegiate Athletic Association Division I team. J. Strength Cond. Res., 20(1):177-83, 2006.

Stølen, T.; Chamari, K.; Castagna, C. \& Wisløff, U. Physiology of soccer: an update. Sports Med., 35(6):501-36, 2005.

Sutton, L.; Scott, M.; Wallace, J. \& Reilly, T. Body composition of English Premier League soccer players: Influence of playing position, international status, and ethnicity. J. Sports Sci., 27(10):1019-26, 2009

Tahara, Y.; Moji, K.; Tsunawake, N.; Fukuda, R.; Nakayama, M.; Nakagaichi, M.; Komine, T.; Kusano, Y. \& Aoyagi K. Physique, body composition and maximum oxygen consumption of selected soccer players of Kunimi High School, Nagasaki, Japan. J. Physiol. Anthropol., 25(4):291-7, 2006.

Triki, M.; Rebai, H.; Abroug, T.; Masmoudi, K.; Fellmann, N.; Zouari, M. \& Tabka, Z. Comparative study of body composition and anaerobic performance between football and judo groups. Sci. Sports, 27(5):293-9, 2012.

Corresponding author:

Jovan Gardasevic, Teacher Assistant

University of Montenegro

Faculty for Sport and Physical Education

Narodne omladine bb

81400 Niksic

MONTENEGRO

E-mail: jovan@ac.me

Received: 07-07-2018

Accepted: 17-10-2018 